\title{
Protection of Shareholders Minority in Joint Stock Company Pursuant to Jordan Companies Law
}

\author{
Mohamad Ali Helalat ${ }^{1}$ \\ ${ }^{1}$ Department of Law, College of Business Administration and Economy, AL Hussein Bin Talal University, \\ Jordan \\ Correspondence: Mohamad Ali Helalat, Department of Law, College of Business Administration and Economy, \\ AL Hussein Bin Talal University, Jordan. E-mail: moh_helalat@yahoo.com
}

Received: July 19, 2016 Accepted: September 8, 2016 Online Published: November 30, 2016

doi:10.5539/jpl.v9n10p22 URL: http://dx.doi.org/10.5539/jpl.v9n10p22

\begin{abstract}
The Joint Stock Company has its role in motivating the economical development of the state. In order to fulfill such role, balancing shall be achieved between Majority and Minority rights or at least restricting the majority arbitrariness in terms of decision making. Such arbitrariness means bringing the investors away from investments in such types of companies which shall, indeed, have its negative influence on the national economy.

The laws and Jordanian companies' law in particular, paid specific attention in terms of minority rights protection, and in the same time recognize its existence, its right to participate in decision making and also to practice control over the majority who manage and run the company's affairs.

Indeed, we cannot ignore the fact that Jordanian legislator tried much to correspond between majority and minority rights or at lease protect the minority rights. In spite of such efforts, we still witness more problems that hinder such issue.

From this point this study came to clarify much of such rights, presenting and analyzing thereof in a way that enable the investor to practice in a way to achieve desired interests.
\end{abstract}

Keywords: companies law, minority rights, majority, Joint Stock Company, shareholders

\section{Introduction}

Joint stock companies are the most important companies in our economical life, as such have its huge financial capacities enabling it to set out big investments in the countries, which the states therein fail to establish such projects as those established by big companies.

Whereas the joint stock companies are considered as capital companies as its capital is generated from senior and minor investors. Due to the invested capital volume in such companies, the most economical activities in many states are controlled by such Joint stock companies.

Generally, this kind of companies are able to raise large amounts of capital by issuing shares, debentures and other types of securities(Lipton, Herzberg, 2015).

Based on the above, we can say that the joint stock company owns the role to motivate the economical development and thus we have a duty to balance between majority and minority rights or at lease prevent arbitrariness of the majority in terms of decision making. Such arbitrariness leads to bring the investors away from investing their money in such companies and further shall work to decrease funds accumulation in the state.

\section{Reasons behind Selecting This Topic}

In this study we have to refer to selecting this topic; protecting minor shareholders in Joint stock company under Jordanian companies law No. (22) Of 1997, as amended, which is attributed to many reasons; subjective and objective ones. The subjective reason lies on our wish to discover such rights reality in effective decision making in the company. While the objective one is represented by defining legal provisions in the Jordanian companies law that set out or ignoring such rights. In other words, determining legislative development extent and stand on legislative protection phenomena decided by the legislator as to minor shareholders.

This subject is classified important as to Jordan's economical and commercial career, as it seeks to encourage 
investment through Joint Stock companies which attract wide part of investors who need legal protection against the majority arbitrariness.

We cannot ignore the reality represented by the Joint companies is still facing problems as to its general assemblies and Directors boards which manage the company, who face the existence of both categories of shareholders; majority and minority, and the consequences thereof in terms of interests interference which jeopardize the company interests.

\section{Research Problem}

From this point the legislator in any state shall maintain legal umbrella to guarantee the minority rights towards majority in a way to confirm such rights, establishing tranquility and avoiding any risks that the company may face.

We may notice that the Jordanian legislator did not follow the full prevention policy of the minority to practice its rights and further he did not make full opportunity available to the minority to practice abuse. Instead the legislator sat out some restrictions on the Majority decisions in order to offer opportunity thereto in order to participate in decision making and practice effective control thereof. Such restrictions are considered safety valve of the minority shareholders to encourage them contribute in investment at tranquil manner.

Many of aforesaid rights need more explanation, presentation and analysis to enable the shareholder practicing thereof in a way to achieve desired goals. Should shareholder is aware of its right he shall be able to take suitable procedure to follow in case of ignoring any of its rights or being prejudiced. Such rights are fixed under law provisions and public system (Ramadan, 2007), thus these rights are neither subject to omission nor negligence.

\section{Research Methodology}

The used methodology herein is the analytical method. We have analyzed the legislative provisions of concern, particularly Jordan Companies law; in order to identify the negative aspects and further avoiding thereof. We also used the descriptive method to monitor legal provisions to shed light on positive aspects, negative aspects, and shortages therein. By carrying out the foregoing, we may form a mean through which, we can weigh the appropriate mean from one side and achieve justice from other side.

\subsection{Research Plan}

Therefore, we can find out that treatment of Minor Shareholders protection issue in Joint stock company in Jordanian companies law, requires to tackle the following basic rights; being effective as to the company existence and shareholders as well. Such rights are stated in sequence manner as follows:

Minority right to review the company documents.

Shareholders right in attending General Assembly meetings.

Shareholder's voting right in general assembly meetings.

Shareholder's right to control over the governing body.

Shareholder's right to set up a legal suit.

Practicing control through auditor.

\subsubsection{Minority Right to Review the Company Documents}

Such right is considered as shareholders right to review the company records, acquire copies and extracts under conditions stipulated for in the law (Muhriz, 2004).

Also this includes that the shareholder shall be authorized to review all the company works through closing accounts and auditor's report thereon as well as the Board report on the company efforts in terms of carrying out its previous year's plan, being dispatched to shareholders with the General Assembly meeting's invitation (Obaidi, 1996).

The Briefing right is adopted by most legislations; as a mean enabling the shareholder to assess the board activities and the extent of performing its duties and tasks, which is considered an indirect control practiced by shareholders on the board. Such information generated for the company enable the shareholder to discuss and be aware of the company real stand.

This right is considered one of the most important means to protect shareholders and practicing control over the company's management. Such right is scheduled for each shareholder even conditions to attend General Assembly meetings are not met by him. 
Basically, this right is not scheduled only as to the General Assembly annual meeting, but before holding this meeting as the shareholder may use his review right before holding the meetings; ordinary or extraordinary.

The companies' law in Jordan regulates, as other legislations, the shareholders right in terms of reviewing or briefing the documents and records to enable him to be aware of the company \& management status. Article No. 144 of the same law imposes the board to invite each shareholder to attend the General Assembly meetings. Such invitations are dispatched via normal post before at least 14 days from scheduled meeting date. The invitation may be served in person against receipt signature. Such article referred to other documents to be attached with the invitation; Agenda, Board report, balance sheet and closing accounts, auditors report as well as explanations.

Such text authorizes each shareholder for such access regardless number of shares he holds in the capital, and to show its opinion on the company business process and further to take its decision. Such access right shall be made available before 14 days from the General Assembly meeting date.

Article 274 also regulates the shareholder right as to access to documents of the company;

a. Each shareholder \& partner in a company shall have access right to documents and records of the company which are filed at the Companies Controller Office and obtains, under auditor consent, certified copy thereof. Also to obtain, via a demand offered to the court, certified copies of any unpublished data against certain fee. "

As for reviewing the records, article No. 98/d in the companies law, states that " Any shareholder in a company may have an access to the shareholders record in respect of its shareholding for whatsoever reason is, and all the records contents due to reasonable reason...)

The foregoing is obvious in Para No. (a) Of same article; the joint stock company shall maintain a record or more including shareholders names, number of shares owned by each, transfer transactions, and any other data of concern to shareholders.

Access right to a member's record in the company offers the opportunity to the shareholder to have access right to the member's record before the General Assembly meeting. The foregoing shall enable the shareholder to know shareholders trends via mutual communication and agreed with them as to matters offered before the General Assembly and facing the Board sovereignty over the General Assembly which shall work positively in ensuring the Minority rights.

Although the Jordanian companies law employed the modern legislative trends, through ratifying shareholders' right, but such law was not clear in defining such right, especially in terms of documents type which are to make available for the shareholders review.

It is worth mentioning herein that the Egyptian legislator stands in the Egyptian companies law, whereas he called to employ the executive list to define the shareholders right and methods of using thereof (Mustafa, 1994).

We can notice that even the Jordanian Legislator states that such access right is a basic one, but it does not offer judicial protection thereto, in case the company denies such right to be practiced by shareholders. The Jordanian Legislator has to include such right to the main system and further any agreement that is directed to reduce the shareholder right herein shall work to bring such agreement void and null.

Moreover, The Jordanian Legislator should confirm the shareholder access right and such issue is to be practiced in certain times, especially for the previous three fiscal years by the company in order to enable the shareholder to be aware directly and permanently of such documents which forms a minority advantage and legislative advantage as well.

Article 281/b states that the General Assembly meeting minute must confirm the legal quorum availability of each meeting, matters discussed in the meeting, decisions issued, number of votes seconding or objecting such decisions, General Assembly deliberations all to be underwritten in the minute which shall be signed by the chair of the meeting, auditor and secretary. Such minute shall be certified in special record prepared in the company for such purpose then copy thereof shall be dispatched to the Board during 15 days from General Assembly Meeting date.

Access to the documents and records is a right granted to the auditor, stipulated for in Article $\mathrm{C}$ of same article also each shareholder right to acquire a certified copy of the meeting minute against certain fees.

Article 140 of the law states about Board responsibility in the Joint Stock Company towards the annual balance sheet, profits and losses statement, annual report on the company future expectation during 3 months and to be presented before General Assembly.

It is worth mentioning herein that the Jordanian legislator ratified the shareholder right as to bring him aware of 
the General Assembly meetings dates and places, agenda in advance which is considered protection of majority arbitrariness. Accordingly the shareholder is authorized to attend General Assembly meetings, participate therein, defend his interests, and shortening the majority arbitrariness possibility.

\subsubsection{Right to Attend General Assembly Meetings}

Addressing invitation for General Assembly meeting is assigned to the Board of directors. Such invitation shall be served 14 days prior to the meeting date. Serving invitation is considered binding, under law, to ensure all shareholders' effective participation in these meetings.

Article 145 refers that the Board of the company shall declare the General Assembly meeting date in two daily local newspapers for at least once before 14 days from meeting date, also he has to declare the meeting date in any of visual and audio media means before maximum 3 days from the General Assembly meeting date.

The legislator, once he offered the General Assembly meetings attendance right to the shareholders, he ratifies participation right in the deliberations; negotiating decisions projects enlisted in the agenda. The meeting chair shall control the deliberations and shall also appoint secretary from among shareholders or company employees to write down the minute of the meeting and decisions adopted therein. Also the chair shall appoint at lease two supervisors to collect and count the votes and declare the outcomes of the voting process, article 181/a.

In order to make sure the most possible shareholders attendants at these meetings, the controller allowed appointing proxy to attend meetings. This is clear in article 179 - companies' law stating that:

a. Each Shareholder in the Joint Stock Company may appoint another shareholder to attend any General Assembly meeting on its behalf via written power of attorney prepared via special slip for such purpose, by the Board and approved by the controller. Such slip shall be deposited in the company headquarters before at least 3 days from date of General Assembly meeting date. Checking such slip shall be done by the controller or his delegate, and the shareholder may appoint any person via power of attorney to attend the meeting on its behalf.

b. The power of attorney is valid to attend any other General Assembly adjourned meeting.

It is noted from such authorization shall allow other shareholders to attend the General Assembly meetings and in the same time shall facilitate General Assembly meeting convening and further fulfill the quorum availability in the General Assembly meeting.

\subsubsection{Shareholder's Right to Vote in the General Assembly}

The shareholders have the right to vote in their interests, provided this does not damage the best

Interests of the company. This right is considered one of the rights of property inherent in the ownership of the share, and one of the basic tools that ensure the active participation of shareholders in

Determining the company's affairs and making decisions related to it (Malin, 2001).

Voting rights in the G. Assembly meetings are granted to shareholders who shall be free and not restricted by any condition. Voting right holds a right of dual nature; i.e. any individual right and occupational right in the same time, in a way which enables the shareholder to protect its individual interest provided that such interest is not in contrary with vocational right; social interest.

Anyway, and whatsoever voting right nature is, this basis is established to protect minor shareholders against majority abuse. Thus, voting right is granted in the common system and any prior agreement as to shareholder waiver of his voting right is considered null. Moreover, any share owner may practice voting right even if respective share is mortgaged.

Voting right is considered, as referred to hereinabove, a right of shareholding partner derived from the shares which he owns either in person or via proxy; in other way it is right which does not need legal provision. Nevertheless, the Jordanian legislator raised this right in article 178 of companies law whereas it refers to voting on the General Assembly Decisions shall be made via the number of votes equal to shares number of each shareholder attending the meeting; either in person or via proxy.

Each shareholder has vote, shareholder voting right proportionality with its share in the company capital; i.e. its shares number in the capital, does not mean votes proportionality.

The principle of Votes Proportionality as to capital is that the shareholder practices its voting in the general assembly, thence participate in the company control and has its role in decision making based on value and number of shares he owns in the company capital(Fathi,2011). 
We notice that the Jordanian legislator adopted the rule that each shareholder has a number of votes based on shares he owns in the company. This rule is serving the equality principle among shareholder.

In order to emphasize such right, the Jordanian legislator guarantees voting right practice, and allow those who cannot attend the general meetings to practice such right via appointing proxy under article 179/a of companies law in Joint Stock companies and delegate its proxy, either from shareholders or T.Ps. to attend meetings on its behalf via written power of attorney or notary power of attorney.

\subsubsection{Shareholder's Right to Control over the Governing Body}

Granting the control right to shareholder over the governing body shall work in pushing the management members to perform their tasks in a loyal and trustful manner. Such control is considered guarantee to encourage Investors to invent their money in such companies' type.

Therefore, the power in the shareholding companies is not based on democratic basis; as such power depends on equity shares in the capital. The foregoing leads to minority of major shareholders to practice their governing power over the company. Such control may be for one shareholder and thus employing its entities to achieve private interests, and at the same time the latest may contradict with the company interests (Al mahi, 2009).

From this point, the concerned laws must include provisions emphasizing this active practice by he minority of shareholders. These texts must not only emphasize on the shareholder control right, but also on active and variable control as well. These laws shall work to grant the respective minority, the legal guarantees in order to face shareholders majority abuse, and further to eliminate the administrative and financial corruption which may cause the company to collapse.

We can say that the control over the Joint Stock Company may be done in various styles; control during company establishment, control following company establishment; i.e. General assembly and Board control, and lastly it could be outside control; i.e. companies controller.

As for the first style we find out that the Jordanian legislator treated such control style to protect the minority of shareholders. Article 107 in the companies' law offers a room for shareholders', who hold not less than $20 \%$ of capital shares, objection as to any item of establishment expenses in the first General Assembly Meeting. Moreover the same article empowers the controller to verify such objection and settle it up. Should such problem is not solved; the objecting shareholders have the right file lawsuit in the competent court.

In order to activate the control during establishment, the Jordanian Legislator, under article 108, imposed the board chairman to provide the auditor with a copy of the General Assembly meeting minute as well as all documents and data offered to the General Assembly by establishers. Such delivery shall be made within 15 days from the General Assembly first meeting. If the company is in breach as to the legal verdict or provision, the controller is entitled to serve warning to the company to straighten up its status otherwise the matter shall be referred to the court.

As far as second style is concerned, we can say that the General Assembly is considered the supreme power in the company, as it issues binding decisions for the departments, elect board members and dismiss them, appoint the auditor (Sami, 2005). So the General Assembly is legally considered the governing body of the company. But in fact, it is not. Shareholders attendance of the General Assembly meetings in order to inquire about the company stand is seldom. Their major concern is to transact with the company shares (Al rawi, 2014).

We can notice that the Jordanian law offers guarantees for all shareholders, especially the minor shareholders to protect their rights. Whereas General Assembly in the company elects the board members via a secret Ballot, then it has the right to dismiss the board. Article 165 in the Companies Law, Para A, offers the General Assembly in the Joint stock Company the right in extraordinary meeting, to dismiss the Board chairman or any board member based on shareholders demand representing not less than $30 \%$ of capital shares. Dismissal demand is offered to the board, copy of which is served to the controller. Same article imposes the board to call for General Assembly Extraordinary meetings during ten days from the date of respective demand. If the board does not invite General Assembly to the meeting the controller may invite for such meeting on the company account.

We may notice herein that even this article is entitled legally to restrict the board, but practically we may notice that the rate defined by the legislator is high which could not be achieved; as establishers do control the boards in such types of companies.

Dismissal right referred to hereinabove could be discussed once offering the dismissal demand at any time, needless to be enrolled, in advance, in the Agenda. The foregoing is confirmed if we refer to Para B of the same article as the General Assembly is granted the right to discuss dismissing any member on the board and hear its 
statement, wither orally or written. The voting takes place on such demand via secret ballot. If the General Assembly adopts such decision, then an alternative must be elected under the rules in force.

We also find that the Jordanian Companies Law offers some positive trends that allow avoiding the majority shareholders control over the Minority. Article 109, Para C, offers right for any shareholder to attend the General Assembly Extraordinary meetings and registered its objection in the meeting minutes, to challenge the court judgment as to in -kind deliveries during 15 days since meeting date. The legislator intended by that, to guarantee avoiding establishers' dominance through offering in kindly shares, as he subject thereof to the General Assembly control as to estimation accuracy and judicial control in case of challenging the value.

In terms of shareholders control over the board chairman and members, article 138 imposed the board chairman and members to serve a written report, including all their shares, whether in this company or otherwise, as well those of spouses and minor children, and further provide copy thereof to the companies controller.

In order to confirm Minority shareholders protection, the companies' law confirms the General Assembly decision legality and mandatory. Under article 183 Para A stating; Decision issued by the General Assembly in joint stock company in any legal meeting is considered binding as to the Board and all shareholders, provided that such decision is adopted under law rules and systems issued pursuant thereto.

But, according to Para B of the same article, it is possible to challenge any meeting or decision legality, the case does not be heard after 3 months to hold a meeting.

As for the third style, of control; external style practiced by the companies controller, we can find out that the companies law contains some provisions which are considered restrictions which prevent the managements from deviation and abuse. Article 273 refers to the Minister \& controller right in taking suitable procedures for companies controlling to verify its compliance with companies' law, its articles of corporation and statutes, including examining the accounts, entries and company commitment to its objectives.

In order to achieve transparency principle the law grants the shareholder the right to direct the controller to practice control over the company's activities. Article 275/a allowed the shareholder who owns not less than $15 \%$ of capital shares or one quarter of the board members, to ask the controller to perform audits as to the company business and records. The controller, if convinced, may delegate an expert or more for such purpose. If any violation is discovered then the Minister may refer the violation to the investigative commission to verify thereof, and study the report prepared by the expert. He has the right to check all papers and documents that it deems fit, and then set out recommendations to the controller or refer the file to the competent court.

On the other hand, the legislator restricts this procedure via Article 275/b that any body seeks audit he has to present bank guarantee to the favor of the Ministry of Industry and trade against a value to be determined by the controller.

Moreover, article 276 grants the Minister based on recommendations from the controller the right to seeking accounts auditing via certain commission formed by him. Such commission may review records and entries of the company, and the company is in default as to such issue, it is considered in breach of companies' law provisions.

The law also imposed the board, via article 140, to disclose the balance sheet, profits and losses statements, income...etc., during 3 months from the end of fiscal year as well the company's forecasts for the coming year, and provide the companies controller with copies of such financial statements, 21 days prior to the General Assembly meeting.

In order to activate the financial and administrative control, the Jordanian legislator via article 168/a bounds the board chairman, member, General Manager, or auditor in the Joint stock company to inform the controller once the company faces financial material losses, or material changes in its management that may affect the shareholders rights or its creditors, subject to perjury if otherwise.

Also same article treat cases where employing the authority in generating private benefits in illegal manner, or commit forgery or practice miss-fidelity act that may affect the company rights or its shareholders or T.P.

Para B authorized the Minister to solve the Board if any of violations takes place, and verify such issues and form commission of expertise members to control the company for six months subject to renewal twice at maximum until inviting the General Assembly meeting to elect new board of directors.

The legislator protected the minority rights and in order to avoid faults in practicing the power, article 182 imposed inviting the controller and auditor to attend the General Assembly meetings; otherwise the meeting is considered void and null. 
We can say that the legislator offered the controller authorities to refer the company in breach as to companies' law to the statutory liquidated or to the court to pay penalties imposed under law or solve the Board of Directors. No doubt, that developing the national economy requires paying much attention to this department, financial and administrative independence to fasten its development in order to launch effective control tools to maintain safe and developing investment environment (Ababneh, 2011).

\subsubsection{Shareholder's Right to Set up a Legal Suit}

There are two key factors in the protection of the shareholders'; the most important of

These are the principles of justice and fairness. In general, the position of minority shareholders in a

Company is inferior to that of the controlling shareholders; Thus, the minority shareholders are in a weak position relative to the other players in the company (Hicks \&Goo, 2008). Thus Jordanian legislator gave the shareholder in a joint stock company the right to control, if mal management is noticed, the legislator allowed to sui the management members, board members or Directors for damages they cause to the shareholders. It is not allowed that the rules of procedures of the company may include depriving sole shareholder from lodging legal action against the company, as this is a basic right for the shareholder which is not subject to be violated as it is the only way to practice control over the Board.

What concerns us is that the Board members responsibility, civil liability for their mistakes and for their mal-management, which originate damages to the company (Al ukaili, 1998). Article 160 states that "the controller and the company or any shareholder may lodge legal action under articles 157,158,159 in the Companies Law".

The Jordanian legislator tackled in article 157, Paragraph (a) the issue of Board violation of the laws and bylaws in force and the companies system. They are responsible towards the company, shareholders and T.Ps or any fault in managing the company.

On the other side, we can notice that the legislator confirmed that such responsibility does not affect any member who offered its written objection in the meeting minute where a false decision is adopted therein.

Article 158 handles some violations which the board may commit in the Joint stock Company. In this article the board chairman, members and G. Manager or any employee in the company, are prohibited to disclose any confidential information, data or secrets of the company to any shareholder or else, otherwise the person in breach is subject to punishment; dismissal or paying compensation for damages caused to the company.

Lastly, we notice that the legislator became more aware of the Board responsibility. Article 159 states that Board chairman and members are jointly responsible towards shareholders for their negligence or failure to manage the company. In case of liquidating the company or suffers deficit in its assets and such issue is attributed to the mal-management of the above mentioned personnel the court may issue its order to hold each of them responsible for damages caused to the company or amounts to be paid in full either jointly or solely.

\subsubsection{Practicing Control through Auditor}

Each Joint stock company shall appoint an auditor to audit its accounts. The auditor cares of the company interests and its duties are to pass the necessary information about the company to shareholders.

In order for the auditor's mission leads to the fullest, it should enjoy complete independence from management devices within the company. This independence is an important safeguard for minority shareholders, as it makes them confident of the impartiality of the auditors and not complicity with members of the Governing Body (Hamdawi, 2010).

The Jordanian legislator inclined to activate such auditor role through amendments on companies' law provisions, to maintain active control to assure shareholders interests. From this point we can touch the legislator attention as to audit legal stand; full chapter has been allocated to talk about this issue; the seventh chapter articles 192-203.

Whereas the auditor is considered part of the control entities in the company, the legislator imposed companies to elect auditor in the General Assembly meeting of the Joint Stock Company.

Auditor plays a significant role to any financial or administrative deviation in the company. His duties include auditing financial and administrative systems, maintain the company assets and equities, liabilities ... etc., (article 193 of companies' law). Moreover the auditor presents its report on the balance sheet and financial statements of the company (article 195/b)

We refer herein to article 199a, through which the auditor is considered shareholder's agent. Para b of same 
article grants each shareholder the right to verify the auditor's report and discussing items therein directly with the auditor. The foregoing confirms the shareholder/s right as to practice such type of control.

It is worth mentioning herein that the auditor attendance as to the General Assembly meetings is considered statutory to enable the shareholders to review the auditor report and financial statements, raise inquires, in direct manner. This has been tacked in article 198 in the companies' law which considered auditor attendance in the General Assembly meeting statutory issue, either in person or via proxy.

Article 200 in the companies' law committed the auditor to report any violation he discovers in the company to the Board chairman and the controller as well.

Lastly, the Jordanian legislator imposed responsibility on the auditor; being responsible before the company and shareholders to compensate for any damages he commits during his audit's course of action.

\section{Conclusion}

We can see herein that the shareholder has rights towards the Joint Stock Company, most of which deal with general order which are protected by companies' law. Such rights should not be compromised, under the company statutory. Any violation of these rights is considered void and null. Such rights include shareholder right to review the company documents, attending the General Assembly meetings, voting right..Etc. The shareholder has the right to sue any of the management members. Finally the shareholder may practice control through the auditor.

We also noticed that the Jordanian legislator tried to reconcile between majority and minority interests. The Jordanian legislator offered many guarantees to protect he shareholder from majority abuse; in other words tried to prevent the majority from abusing the minority.

We can summarize the most important outcomes of this research:

1) In order to maintain the shareholder voting right, the Jordanian Legislator sets our rules to appoint a proxy to represent the absent shareholder in attending the General Assembly meetings on its behalf.

2) The Jordanian companies' law provisions include some positive trends that prevent the majority of shareholders' dominance over the minority rights. Article 109, Para C allows the shareholder who attends General Assembly Extraordinary meeting and confirms his objection in the meeting minute, challenge before the court, in-kind deliveries during 15 days from meeting date. The foregoing is intended to limit the establishers domain which could be achieved via in kind shares offerings, as the legislator subject thereof to the General Assembly control in terms of assessing thereof and judicial control through challenging its value assessment.

3) The Jordanian law offers guarantees for all shareholders, particularly to minority thereof to protect their rights and stop abuses of the majority. Article 165 of companies' law decided the General Assembly right in its extraordinary meeting to dismiss the chairman of the board or any member therein based on shareholder demand that represent $30 \%$ of the company shares. The dismissal demand is presented before the board of directors and copied to the auditor. Same article imposed on the board of directors to invite for extraordinary General Assembly meeting during ten days from demand date. Also if the Board fails to invite the General Assembly meeting the controller shall act accordingly on the company account. We notice herein that the rate which is defined by the legislator to justify such meeting is relatively high, and is not easy to achieve, if we take into consideration that the establishers who control the Boards of Directors in such companies type.

4) The Jordanian legislator act in good manner once it offers the shareholders the dismissal right as stated in Article 165/a. which allows such issue to be discussed at any time, needless to be inserted in the Agenda. The foregoing is confirmed via Para (b) of the same article, whereas the General Assembly grants the right to discuss the dismissal of any board member, hear his statements either orally or in writing. In order that the Board is confident that the General Assembly is the supreme power in the company, and thus authorized to dismiss any member of the board to maintain company and shareholders' interests.

5) The Legislator offers the shareholder the right to seek legal channels directly to challenge the legality of any meeting of any decision adopted by the General Assembly to protect the shareholders rights and maintaining the judicial protection over the majority abuse. 
6) In order to achieve the transparency principle, the law offers a room for shareholders to apply before the controller to audit the company's business. Article 275/a allowed the shareholders who own $15 \%$ of the capital shares or Quarter of Board members, to apply before the controller to check up the company activities and its records. The controller, if convinced, may delegate expert for such purpose. Should such audit show any violation the minister shall have the right to refer the matter to the investigation commission to issue its report thereto. The commission has the right to recommend to the controller to apply certain recommendations in that regard or refer the issue to the competent

7) We also point out that Article 199/a tackles the auditor being agent of shareholders, Para (b) grants every shareholder to inquire from the auditor about its report and discussing thereof during the meeting of the General Assembly We believe that the legislator herein do confirm the shareholders right in terms of control. It is no necessary to have a certain number of shareholders to practice such type of control, as one shareholder is enough for this job.

8) The legislator as well, does not limit the auditor duties to the company accounts only, but its duties include oversight of many aspects of the company; protecting and controlling legal, financial and administrative matter of concern to the company.

\section{References}

Ababneh, M. (2011). the role of the Companies Controller Department, in good corporate governance. Retrieved from http://www.ccd.gov.

Al Mahi, H. (2009). Shareholding companies governance as preventive procedure against bankruptcy, work paper presented to the 4th. Scientific conference of Dubai Police academy from 15-17/3/2009, p 96.

Al rawi, M. (2014). The application of the legal standards of governance and its impact on ensuring the rights of minority shareholders in the company's contribution, The magazine policy and law books, Issue 11, p.188.

Al ukaili, A. (1998). Explanation of the Commercial Code, Part IV, the House of Culture for Publishing and Distribution, Amman, p.396.

Andrew, H., \& Goo, S. H. (2008). Cases and Materials on Company Law (6th ed.). Oxford University Press. p. 425.

Fathi, M. (2011). Shareholder right in the shareholding company, comparative law study, Abe Baker university Telmisan, p 74.

Hamdawi, A. (2010). The role of auditors in the protection of minority shareholders in joint stock companies, research published in the portal legal and judicial location and the Moroccan Ministry of Justice. Retrieved from http://adala.justice.gov.ma

Lipton, \& Herzberg. (2015). Understanding Company Law (18th ed.). Thomson Reuters (Law book Co), p.70.

Mallin, Ch. (2001). Institutional investors and voting practices: An international comparison. Corporate Governance: An International Review, 9(2), 119. https://doi.org/10.1111/1467-8683.00236

Muhriz, A. M. (2004). Al Waseet in commercial companies (2nd ed.). Maaref house, p. 703.

Mustafa, A. B.(1994). Protecting shareholder Minority in Joint Stock, Published in Legal Study Magazine, issued by faculty of law, Asute University, 16th, p. 229.

Obaidi, A. F. (1996). underwriting in Joint stock company capital. house of Culture, Amman, p211

Ramadan, E. M. A. (2007). Protecting shareholder in Joint Company. legal books house, p 7.

Sami, F. M. (2005). Commercial companies, public and private judgments, comparative study. the House of Culture for Publishing and Distribution, Amman, p.483.

\section{Copyrights}

Copyright for this article is retained by the author(s), with first publication rights granted to the journal.

This is an open-access article distributed under the terms and conditions of the Creative Commons Attribution license (http://creativecommons.org/licenses/by/4.0/). 